\title{
Pengembangan LKS Berbasis Etnomatematika pada Materi Transformasi Geometri Kelas XI SMA
}

\author{
Yusril Achmad Fatoni ${ }^{1 *}$, Dimas Danar Septiadi ${ }^{2}$ \\ ${ }^{1}$ Universitas Jember, Jember, Jawa Tinur \\ ${ }^{2}$ Institut Agama Islam Negeri Madura, Pamekasan, Jawa Tinur \\ "E-mail: dianarahayu513@gmail.com
}

\begin{abstract}
Abstrak
Bahan ajar merupakan salah satu komponen terpenting yang harus ada didalam proses pembelajaran. Salah satu bahan ajar yang dapat digunakan yaitu lembar kerja siswa. LKS merupakan salah satu bahan ajar yang digunakan oleh pendidik dalam proses belajar-mengajar dengan bentuk bahan ajar yang lebih praktis, menarik, serta mempermudah peserta didik dalam menerima materi. LKS yang dikembangkan merupakan LKS berbasis etnomatematika dengan konteks rumah tembakau pada materi transformasi geometri kelas XI. Prosedur pengembangan yang digunakan mengikuti model pengembangan ADDIE (Analysis, Design, Development, Implementation, Evaluation). Penelitian ini disesuaikan dengan keadaan masa pandemi, sehingga penelitian hanya menggunakan uji validasi ahli dan kepraktisan. Ahli yang digunakan adalah ahli materi, ahli desain, dan ahli pendidikan matematika. Didapat rata-rata kevalidan $85.6 \%$ dengan kriteria sangat valid. Untuk kepraktisan diperoleh rata-rata kepraktisan 83.2\% dengan kriteria sangat praktis
\end{abstract}

Kata kunci: Etnomatematika, LKS, Pengembangan

\section{PENDAHULUAN}

Bahan Ajar merupakan salah satu komponen terpenting yang harus ada didalam proses pembelajaran (Hanafi dan M. Sain, 2014). Menurut Belawati (2003) bahan ajar adalah semua bentuk apapun baik berupa teks, foto, audio, video atau animasi yang dapat digunakan siswa sebagai sarana pembelajaran. Priyanto (dalam Prasetiyo, 2017) berpendapatbahwa bahan ajar digunakan sebagai salah satu sumber acuan bagi pendidik. Selanjutnya, Sitohang dan Sibuea (2015) mendefinisikan bahan ajar sebagai perangkat substansi pelajaran yang mencakup isi kurikulum yang harus dicapai peserta didik dalam pembelajaran dan disusun sistematis. Pengertian lainnya terkait dengan bahan ajar yaitu segala bentuk bahan yang digunakan untuk membantu guru dalam melaksanakan proses pembelajaran di kelas (Depdiknas, 2008). Salah satu bahan ajar yang dapat digunakan yaitu dengan mengaplikasikan Lembar Kerja Siswa (LKS) pada siswa. LKS adalah lembar kegiatan yang berisikan informasi dan instruksi dari guru kepada siswa agar dapat mengerjakan sendiri suatu aktivitas belajar melalui praktik atau penerapan hasil belajar untuk mencapai tujuan pembelajaran (Ariaji dan Abubakar, 2017). Dengan menggunakan LKS, guru 
dapat memberikan panduan kepada siswa yang dapat digunakan untuk melakukan penyelidikan atau pemecahan masalah sehingga siswa menemukan sendiri konsep materi yang dipelajari. LKS dapat diterapkan kepada seluruh mata pelajaran tidak terkecuali matematika.

Matematika merupakan ilmu dasar yang memuat aspek terapan dan penalaran, sehingga sangat berperan penting dalam ilmu pengetahuan, teknologi, dan juga budaya. Menurut Anas (2015) matematika adalah suatu ilmu untuk menemukan informasi dari pengalaman dan pengetahuan tentang menghitung. Sampai saat ini, mata pelajaran matematika masih dianggap pelajaran yang sulit, bahkan banyak siswa yang beranggapan matemaika sebagai mata pelajaran yang menakutkan (Novita dan Anita, 2006). Hal ini adalah suatu pertanyaan yang harus segera dijawab oleh para calon pendidik matematika sebab tujuan dari pembelajaran matematika yaitu melatih cara berpikir dan bernalar dalam menarik kesimpulan, mengembangkan kemampuan memecahkan masalah serta mengembangkan kemampuan menyampaikan informasi atau mengkomunikasikan ide-ide melalui lisan, tulisan, gambar, grafik, peta, diagram, dan sebagainya, dengan mencari solusi-solusi baru, salah satunya dengan menggunakan etnomatematika (Nurul, 2017).

Istilah etnomatematika diperkenalkan oleh D'Ambrosio, seorang matematikawan Brasil pada tahun 1977 (Astri, dkk., 2017) dengan kata lain, etno mengacu pada anggota kelompok dalam lingkungan budaya yang didefinisikan oleh tradisi budaya, kode, symbol, mitos, dan caracara khusus yang digunakan untuk alasan dan menyimpulkan. Jadi etnomatematika adalah suatu aktivitas kehidupan dari elemen-elemen masyarakat yang menjadi rutinitas atau ciri khas dari suatu daerah yang memilikikonsep-konsep matematika. Selain itu, etnomatematika juga dapat menjadi alternative un tuk mengubah pemikiran masyarakat yang beranggapan matematika itu sulit untuk dipahami. Salah satu warisan budaya yang dimiliki oleh bangsa kita yaitu Rumah Tembakau, sesuai dengan namanya, bangunan ini merupakan bangunan yang berbentuk menyerupai rumah masyarakat pada umunya dan berfungsi sebagai penyimpan tembakau. Rumah tembakau masih banyak ditemukan di Kabupaten Jember, bangunan ini sudah ada sejak tahun 1850 atau pada masa penjajahan Belanda. Pembangunan pabrik tembakau di Jember dimulai sekitar tahun 1850 dan diambil alih oleh pemerintah Indonesia pada tahun 1957 (Saraswati, 2008). Jember merupakan salah satu kebupaten penghasil tembakau yang cukup besar sehingga tembakau dijadikan ikon dari Kabupaten Jember. Tembakau dari Jember telah diekspor ke berbagai negara seperti Jerman, Malyasia, dan negara lainnya. Rumah tembakau terbuat dari bambu kering dan daun tebu kering. Rumah tembakau memiliki fungsi untuk mengeringkan daun tembakau yang sudah dipetik, tidak hanya mengeringkan, namun suhu ruangan dan angin yang masuk menjadi peran penting dalam pengelohan tembakau, rumah tembakau 
merupakan hal yang tidak dapat dilepaskan dari proses ini.

Perlunya guru dalam mengimplementasika unsur-unsur kebudayaan dalam kegiatan pembelajaran sangat perlu dilakukan, untuk itulah Zeichner menyarankan perlunya guru mengimplementasikan prinsip-prinsip kebudayaan dalam kegiatan pembelajaran, baik sebagai bahan pengantar ataupun aktivitas sosial masyarakat yang dijadikan sumber pembelajaran. Hal ini diperkuat oleh Bishop bahwa integrasi nilai-nilai budaya yang ada di masyarakat sekitar dalam pembelajaran memberikan pengaruh pada perilaku individu, serta berperan besar dalam perkembangan pemahaman individu termasuk pembelajaran matematika. Berdasrkan hasil wawancara yang dilakukan peneliti kepada guru matematika wajib kelas XI di SMAUnggulanBPPTDarusSholahJember, didapat bahwa mata pelajaran matematika masih dianggap hal yang sulit, disebabkan materi ataupun permasalahan matematika yang terdapat dalam bahan ajar terkadang tidak sesuai dengan permasalahan matematika yang ditemukan di kehidupan sehari-hari. Salah satu matei matematika tersebut yaitu transformasi geometri. Oleh karena itu, diperlukan proses internalisasi etnomatematika ke dalam kegiatan pembelajaran matematika terutama pada materi transformasi geometri untuk kelas XI SMA.

\section{METODE}

Jenis penelitian yang digunakan dalam penelitian ini yaitu penelitian dan pengembangan atau (research and development). Pada penelitian ini model penelitian yang digunakan adalah model desain instruksional ADDIE (AnlysisDesain-Develop-Implement-Evaluate). Model pengembangan ADDIE menggunakan lima langkah yaitu: (1) analisis kebutuhan, (2) desain, (3) pengembangan, implementasi, (5) evaluasi (Nur dan Wahyu, 2020).

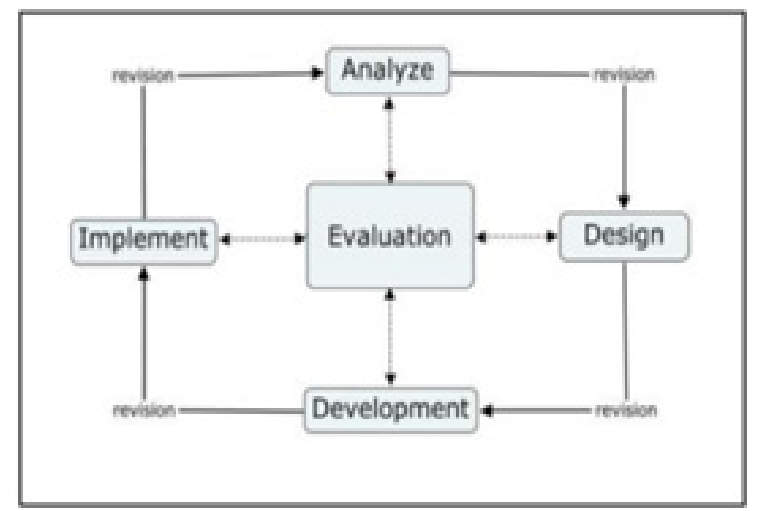

Gambar 1. Bagan Pengembangan ADDIE (Noviyanti dan Gading, 2020)

Sebelum diujicobakan, produk bahan ajar maetmatika yang berbentuk LKS divalidasi terlebih dahulu oleh ahli materi, desain, dan pendidikan matematika yang kemudian dilakukan revisi tahap I. Produk yang telah direvisi diujicobakan dalam skala kecil yaitu 6 siswa kelas XI SMA Unggulan BPPT Darus Sholah secara random. Produk yang sudah diujicobakan dievalusi untuk mengetahui kevalidan produk dan kemudian dilakukan revisi tahap II. Produk hasil revisi tahap kedua diujicobakan dalam skala besar yaitu dalam satu kelas yang terdiri dari 30 siswa. Uji coba dilakukan secara online karena keadaan pandemi covid-19. Uji coba dilakukan dengan membentuk WhatsApp Group terlebih dahulu dan setelah mengirimkan LKS serta link Google 
Form untuk mengisi angket respon siswa. Data yang diperoleh dari penelitian dan pengembangan ini adalah data kuantitaif, yang digunakan dalam mengukur kevalidan serta kepraktisan LKS yang dikembangkan. Rumus yang digunakan untuk penilaian kepraktisan dan kevalidan yaitu:

Nilai Persentase $=\frac{\text { Nilai yang dioeroleh }}{\text { Total nilai }}$

Kriteria kevalidan LKS disajikan pada Tabel 1 dan Tabel 2 berikut.

Tabel 1. Kriteria Kevalidan

\begin{tabular}{ccc}
\hline No & Skor & Kriteria \\
\hline 1 & $80 \%-100 \%$ & Sangat Valid \\
2 & $66 \%-79 \%$ & Valid \\
3 & $56 \%-65 \%$ & Cukup Valid \\
4 & $40 \%-55 \%$ & Kurang Valid \\
5 & $0 \%-39 \%$ & Sangat Kurang Valid \\
\hline
\end{tabular}

(Mateus, 2019)

Tabel 2. Kriteria Kepraktisan

\begin{tabular}{ccc}
\hline No & Skor & Kriteria \\
\hline 1 & $80 \%-100 \%$ & Sangat Praktis \\
2 & $66 \%-79 \%$ & Praktis \\
3 & $56 \%-65 \%$ & Cukup Praktis \\
4 & $40 \%-55 \%$ & Kurang Praktis \\
5 & $0 \%-39 \%$ & Sangat Kurang Praktis \\
\hline
\end{tabular}

(Mateus, 2019)

\section{HASIL DAN PEMBAHASAN}

Produk yang dikembangkan berupa LKS berbasis etnomatematika pada konteks rumah tembakau. Proses pengembangan produk LKS melalui tahapan ADDIE, yaitu:

\section{Analysis (Analisis)}

a. Hasil Analisis Kebutuhan

Wawancara dilaksanakan pada tanggal 20 November 2020 dengan narasumber
Bu Fais, guru mata pelajaran matematika di SMA Unggulan BPPT Darus Sholah. Berdasarkan wawancara yang diperoleh dari narasumber, bahwa di SMA Unggulan BPPT Darus Sholah pada tahun pelajaran 2020/2021 menggunakan kurikulum yang telah berlaku yakni kurikulum 2013. Begitupula baik untuk Kompetensi Dsar (KD) maupun Kompetensi Inti (KI), mereka jugs ,menggunakan apa yang telah dianjurkan oleh pemerintah.

Di SMA Unggulan BPPT Darus Sholah khususnya pada mata pelajaran matematika, bahan ajar yang digunakan merupakan buku paket yang disediakan oleh pemerintah saja. Bahan tersebut kurang memenuhi kebutuhan siswa. Disela-sela wawancara peneliti memberikan ide tentang pengembangan LKS berbasis etnomatematika. Guru mata pelajaran sangat setuju dengan ide yang peneliti berikan. Menurut beliau memang perlu adanya inovasi bahan ajar untuk meningkatkan proses pembelajaran.

b. Hasil Analisis Karakteristik Siswa

Analisis karakteristik siswa merupakan tahap yang digunakan peneliti untuk mengetahui karakteristik siswa yang menjadi dasar peneliti untuk menyusun bahan ajar yang akan dikembangkan. Bahan ajar yang sesuai dengan karakter siswa diharapkan dapat meningkatkan hasil belajar siswa. Berdasarkan observasi yang dilakukan peneliti pada tanggl 20 November 2020, secara umum siswa mengikuti kegiatan belajar-mengajar dengan baik, walaupun pembelajaran diterapkan secara daring. Namun, hanya beberapa siswa yang 
aktif didalam pembelajaran berlangsung. Selain itu, siswa juga tampak bingung dalam menyelesaikan soal-soal yang diaplikasikan dalam kehidupan seharihari. Oleh karena itu diperlukan inovasi baru dalam bahan ajar yang digunakan ketikaprosesbelajarmengajarberlangsung. Berdasarkan hasil analisis tersbut, bahan ajar berbasis etnomatematika pada rumah tembakau dapat diterapkan pada siswa SMA Unggulan BPPT Darus Sholah kelas XI dan dapat diharapkan membantu untuk meningkatkan hasil belajar siswa.

c. Hasil Analisis Etnomatematika

Objek etnomatematika yang dipilih yaitu rumah tembakau, oleh karena itu dilakukan analisis rumah tembakau pada 01 Oktober 2020. Berdasarkan data hasil observsi awal pada penelitian ini dilakukan di salah satu rumah tembakau yang ada di daerah Ajung, Kabupaten Jember, didapatkan terdapat konsep matematika yang ada di dalam rumah tembakau, diantaranya yaitu konsep geometri, phytagoras, panjang, sudut, kesejajaran, perpotongan garis, dan transformasi geometri.

Konsep transformasi geometri yang ada yaitu dilatasi, trasnlasi, rotasi, dan refleksi. Berikut konsep transformasi geometri yang ada pada rumah tembakau:

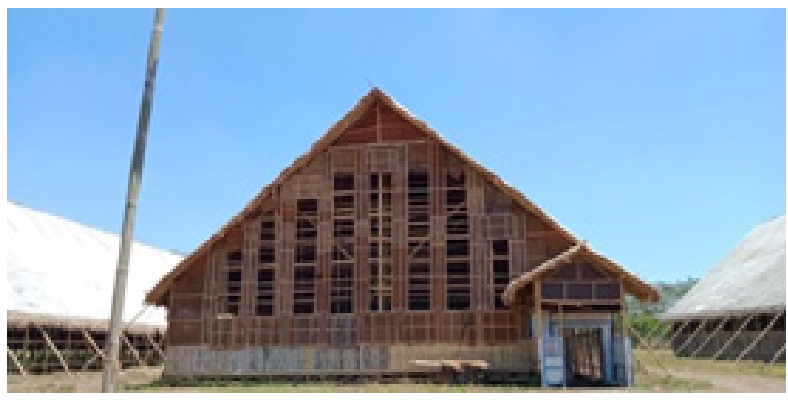

Gambar 2. Dilatasi Pada Rumah Tembakau

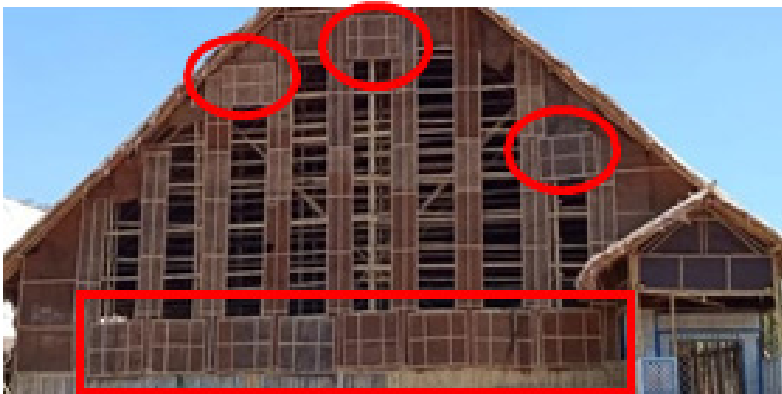

Gambar 3. Translasi pada Rumah Tembakau

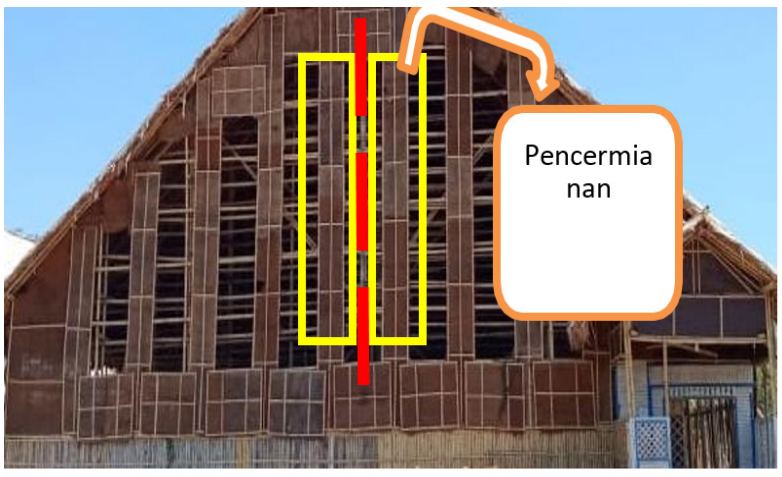

Gambar 4. Refleksi pada Rumah Tembakau
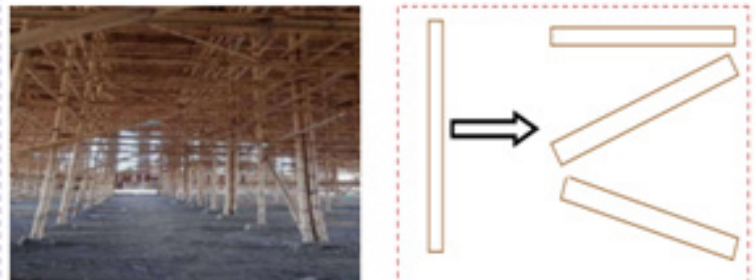

Gambar 4. Rotasi pada Rumah Tembakau

Berdasarkan hasil analisis tersebut, rumah tembakau sangat cocok untuk diaplikasikan dalam bahan ajar yang peneliti harapkan.

\section{Design (Perancangan)}

Adapun langkah yang dilakukan pada tahap ini yaitu pengumpulan buku yang mendukung terwujudnya LKS, pemilihan desain yang sesuai, pemilihan layout sesuai dengan karakteristik siswa SMA, pengembangan desain LKS, pengumpulan buku yang berkaitan dengan materi Transformasi Geometri Kelas XI, pengembangan draf product serta menyiapkan angket yang digunakan untuk menvalidasi produk LKS. Langkah 
yang dilakukan pada tahap ini adalah melakukan penyusunan desain LKS serta melakukan penyusunan desain instrumen.

\section{a. Penyusunan Desain LKS}

Rancangan penelitian pengembangan desain LKS berbasis etnomatematika dilakukan dengan langkah-langkah berikut: (1) Menentukan judu LKS berdasrakan hasil analisis, judul yang sesuai yaitu LKS Berbasis Etnomatematika Rumah Tembakau, (2) Perumusan KI dan $\mathrm{KD}$, (3) Ulasan mengenai rumah tembakau, (4) Penyusunan topic materi transformasi geometri dimulai dengan materi translasi, refleksi, rotasi, dan dilatasi, (5) Fitur math corner yang berisikan fakta-fakta matematika dan math figure yang berisikan tokoh-tokoh matematika, (6) Menentukan bentuk evaluasi yang bertujuan untuk mengetahui sejauh mana siswa memahami materi transformasi geometri dengan menggunakan LKS ini, (7) Ringkasan rumus, (8) Proyek dan Refleksi yang bertujuan agar siswa dapat mengeksplorasi mengenai materi yang ada di dalam LKS, dan (9) Penilaian diri dengan tujuan mengetahui materi yang sudah dan belum dikuasai oleh siswa selama pembelajaran.

\section{b. Penyusunan Desain Instrumen}

Penyusunan desain instrumen bertujuan untuk menilai kevalidan kepraktisan LKS. Instrumen penilaian LKS berupa Lembar Validasi Ahli Materi, Lembar Validasi Ahli Desain, dan Lembar Validasi Ahli Pendidikan Matematika, lembar validasi tersebut digunakan dalam menilai LKS. Selain itu juga terdapat Angket Respon Siswa dan Angket Respon Guru yang bertujuan untuk menilai kepraktisan LKS. Sebelum diberikan kepada para ahli, guru, dan siswa, terlebih dahulu desain penilaian dikoreksi oleh dosen pembimbing, setelah dinyatakan sudah sesuai, lembar penilaian tersebut langsung diberikan kepada para ahli, guru, dan siswa utuk mendapatkan data kevalidan dan kepraktisan LKS, berikut masingmasing instrumen penialain LKS: (1) Lembar validasi ahli materi, (2) Lembar validasi ahli pendidikan matematika, (3) Lembar validasi ahli desain, (4) Angket respon siswa, dan (5) Angket respon guru.

\section{Development (Pengembangan)}

Tahap ini merupakan realisasi produk yiatu LKS matematika berbasis etnomatematika dan instrumen penelitian.

\section{a. Pengembangan LKS}

Perancangan ini, dilakukan setelah melakukan analisis karakteristik siswa, diketahui bahwa siswa cenderung kurang semangatsertajenuhketika proseskegiatan belajar mengajar berlangsung. Maka dari itu, perancangan LKS dilakukan semenarik mungkin untuk mengatasi permasalahan yang ada. Dalam perancangan ini terdapat 3 bagian, yaitu bagian awal, bagian isi, dan bagian akhir. Bagian awal terdiri atas; (1) Sampul depan, (2) Daftar isi, (3) Peta konsep, (4) Pengalaman belajar dan petunjuk kerja; dan (5) Rumah tembakau. Bagian isi terdiri atas; (1) Transformasi geometri, (2) Translasi, (3) Refleksi; (4) Rotasi, (5) Dilatasi, (6) Ringkasan rumus, dan (7) Math corner dan math figure. Bagian Akhir terdiri atas; (1) Proyeksi dan refleksi, (2) Penilaian diri, (3) Daftar pustaka, (4) Sampul belakang LKS. 


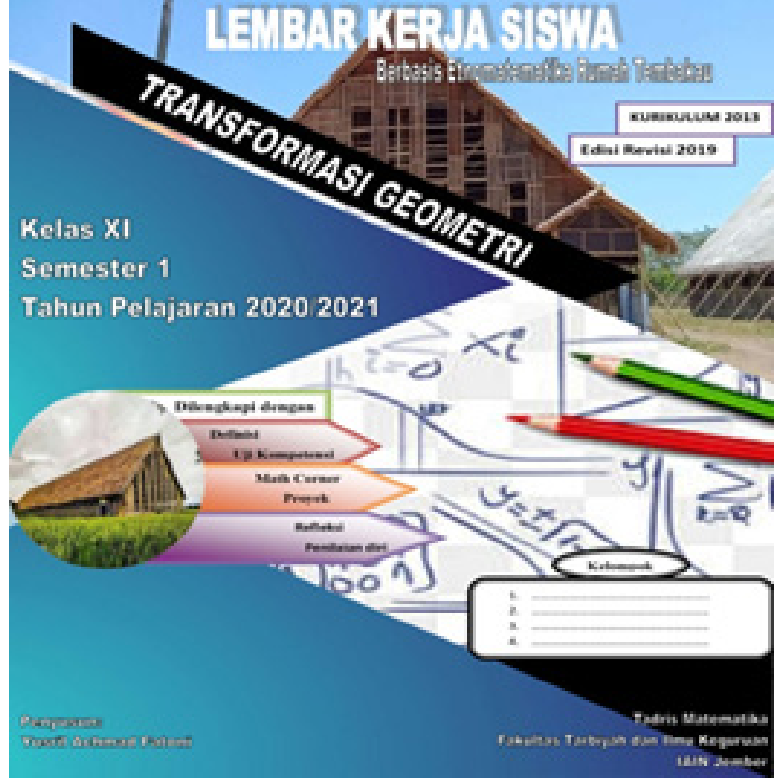

Gambar 6. Sampul Depan LKS
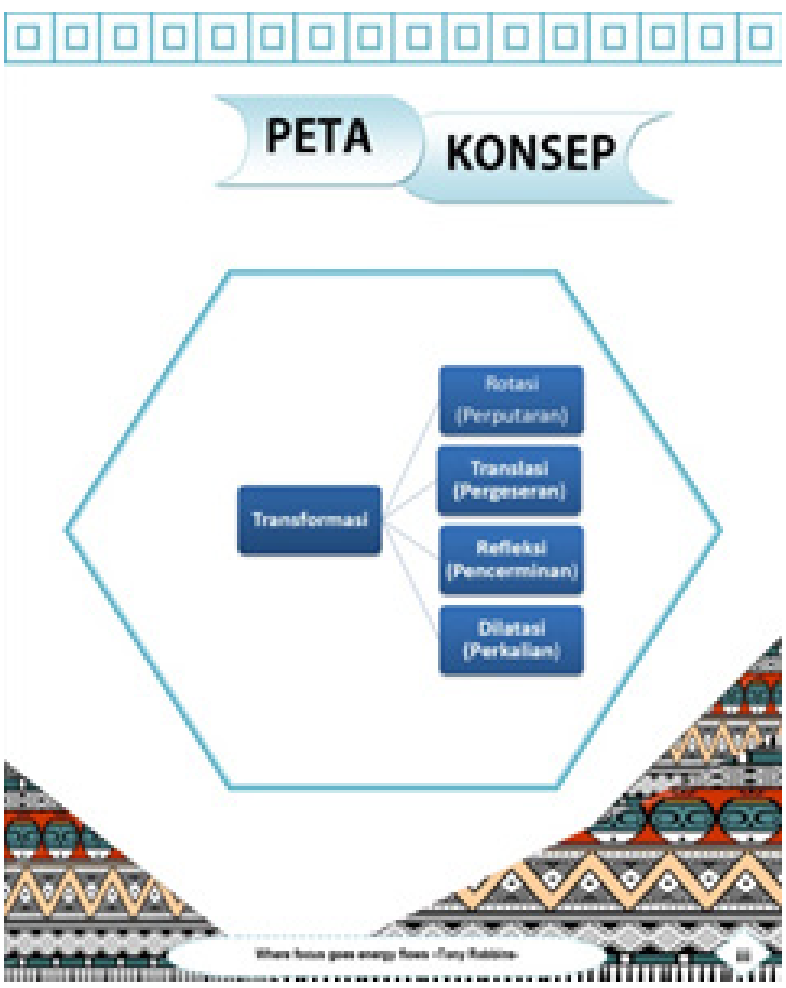

Gambar 7. Peta Konsep LKS

b. Pengembangan Instrumen Penelitian

Terdiri atas lembar validasi para ahli dan respon siswa serta guru. Berikut tabel instrumen penelitian.

Tabel 3. Pernyataan Lembar validasi Ahli Materi

\begin{tabular}{ll}
\hline No & \multicolumn{1}{c}{ Pernyataan } \\
\hline 1 & $\begin{array}{l}\text { Penggunaan symbol dalam LKS sudah } \\
\text { sesuai dengan materi yang disampaikan. }\end{array}$ \\
\hline
\end{tabular}
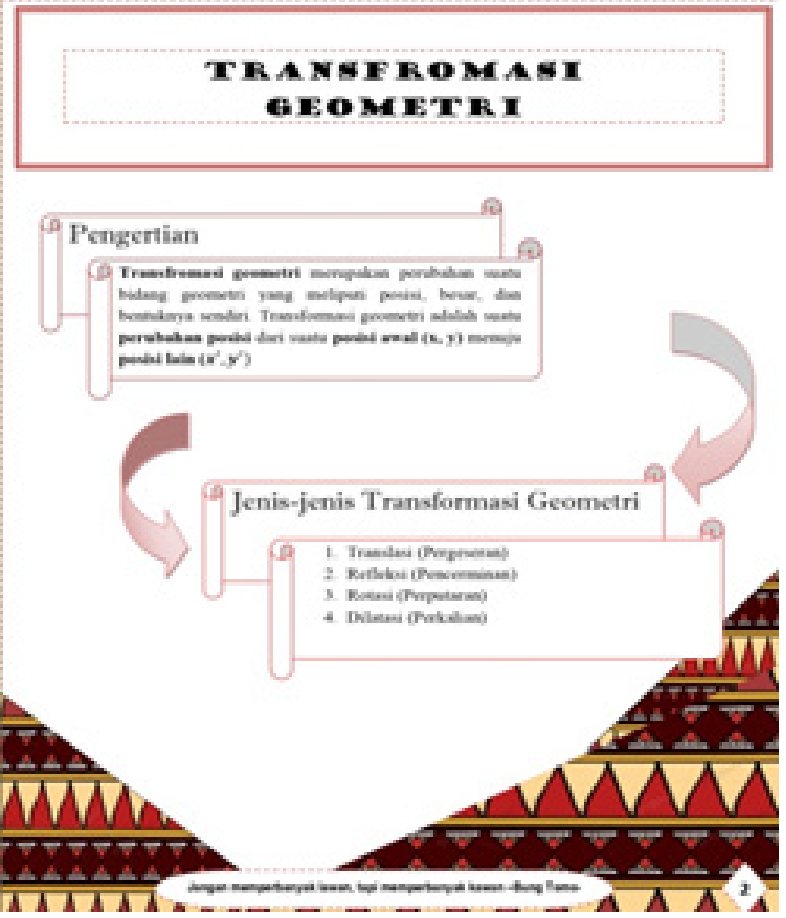

Gambar 8. Transformasi Geometri

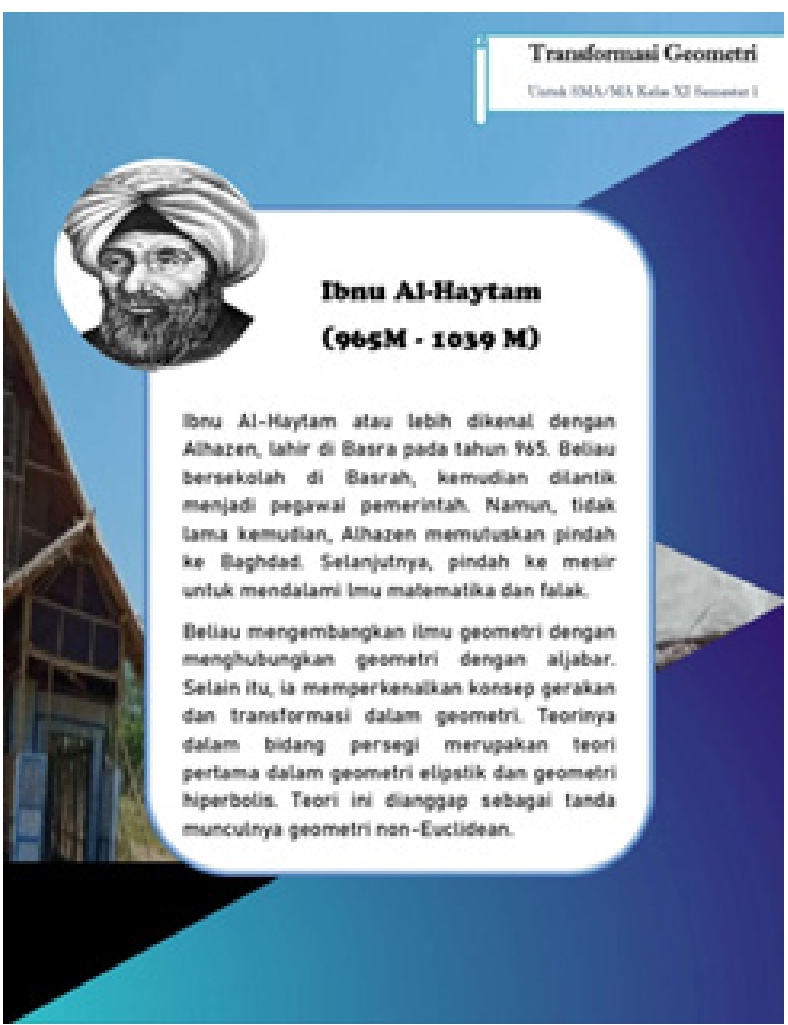

Gambar 9. Sampul Belakang LKS

\begin{tabular}{ll}
\hline No & \multicolumn{1}{c}{ Pernyataan } \\
\hline 2 & $\begin{array}{l}\text { Kekonsistenan dalam penulisan symbol } \\
\text { matematika. }\end{array}$ \\
3 & $\begin{array}{l}\text { Pertanyaan sesuai dengan materi trans- } \\
\text { formsi geometri. }\end{array}$ \\
\hline
\end{tabular}


Indonesian Journal of Mathematics and Natural Science Education, 2 (2), 2021

Diana Rahayu, R. Ading Pramadi, Meti Maspupah, Tri Wabyuni Agustina

\begin{tabular}{ll}
\hline No & \multicolumn{1}{c}{ Pernyataan } \\
\hline 4 & $\begin{array}{l}\text { Materi pembelajaran sesuai dengan ting- } \\
\text { kat kemampuan siswa. }\end{array}$ \\
5 & $\begin{array}{l}\text { Kesesuaian tingkat kesulitan soal dan } \\
\text { materi dengan perkembangan psikologi } \\
\text { siswa. }\end{array}$ \\
6 & $\begin{array}{l}\text { Penggunaan soal cerita mengarah pada } \\
\text { pemahaman konsep. }\end{array}$ \\
7 & $\begin{array}{l}\text { Konten matematika sudah sesuai dengan } \\
\text { konsep transformsi geometri. }\end{array}$ \\
8 & $\begin{array}{l}\text { Konteks budaya memberikan inspirasi } \\
\text { pembelajaran matematika yang bermakna. }\end{array}$ \\
\hline
\end{tabular}

Tabel 4. Pernyataan Lembar validasi Ahli Media

\begin{tabular}{ll}
\hline No & \multicolumn{1}{c}{ Pernyataan } \\
\hline 1 & Kejelasan penulisan judul pada LKS. \\
2 & Kesesuaian ukuran huruf pada teks LKS. \\
3 & $\begin{array}{l}\text { Penggunaan kata pada LKS sudah jelas } \\
\text { dan sesuai. }\end{array}$ \\
4 & Kejelasan tulisan pada LKS. \\
5 & Kemudahan alur cerita pada soal LKS. \\
6 & Desain LKS sesuai dengan siswa kelas XI. \\
7 & Desain LKS menarik. \\
8 & Pemilihan warna LKS. \\
9 & Bnetuk gambar jelas dan menarik. \\
10 & Tata letak gambar sesuai. \\
11 & LKS sebagai sumber belajar. \\
12 & LKS mampu menarik minat belajar siswa. \\
\hline
\end{tabular}

Tabel 5. Pernyataan Lembar validasi Ahli Pendidikan Matematika

\begin{tabular}{ll}
\hline No & \multicolumn{1}{c}{ Pernyataan } \\
\hline 1 & Materi sesuai silabus \\
2 & Materi sesuai dengan KI dan KD \\
3 & $\begin{array}{l}\text { Kesesuaian materi dengan indikator yang } \\
\text { akan dicapai }\end{array}$ \\
4 & $\begin{array}{l}\text { Manfaat materi untuk menambah wawa- } \\
\text { san siswa }\end{array}$ \\
5 & $\begin{array}{l}\text { Bahasa yang digunakan sesuai dengan } \\
\text { kaidah bahasa Indonesia }\end{array}$ \\
6 & $\begin{array}{l}\text { Materi pembelajaran mudah dipahami } \\
7\end{array}$ \\
$\begin{array}{l}\text { Kejelasan materi dalam tujuan pembela- } \\
\text { jaran }\end{array}$ & $\begin{array}{l}\text { Pemberian kata-kata motivasi memiliki } \\
\text { nilai pendidikan }\end{array}$ \\
9 & Kejelasan dalam memberikan informasi \\
\hline
\end{tabular}

\begin{tabular}{ll}
\hline No & \multicolumn{1}{c}{ Pernyataan } \\
\hline 10 & $\begin{array}{l}\text { Penggunaan bahasa yang efektif dan } \\
\text { efisien }\end{array}$ \\
11 & $\begin{array}{l}\text { Pertanyaan mampu mengungkapkan } \\
\text { sikap spesifik dari pengalaman belajar }\end{array}$ \\
12 & $\begin{array}{l}\text { LKS berbasis etnomatematika pada rumah } \\
\text { tembakau mampu memberikan pema- } \\
\text { haman tentang matematika khususnya } \\
\text { materi transformasi geometri }\end{array}$ \\
13 & $\begin{array}{l}\text { Pemberian fitur "math corner" menambah } \\
\text { wawasan siswa }\end{array}$ \\
14 & $\begin{array}{l}\text { Adanya fitur "math figure" mampu } \\
\text { memberikan pengetahuan tentang tokoh } \\
\text { matematika pada siswa }\end{array}$ \\
\hline
\end{tabular}

Tabel 6. Angket Respons Guru

\begin{tabular}{|c|c|}
\hline No & Pernyataan \\
\hline 1 & Tampilan halaman cover LKS menarik \\
\hline 2 & $\begin{array}{l}\text { Setiap judul LKS ditampilkan dengan jelas } \\
\text { sehingga dapat menggambarkan isi LKS }\end{array}$ \\
\hline 3 & $\begin{array}{l}\text { Pemilihan jenis huruf, ukuran, dan spasi } \\
\text { yang digunakan sesuai sehingga memper- } \\
\text { mudah siswa dalam membaca LKS }\end{array}$ \\
\hline 4 & $\begin{array}{l}\text { Perpaduan antara gambar dan tulisan } \\
\text { dalam LKS menarik perhatian }\end{array}$ \\
\hline 5 & $\begin{array}{l}\text { LKS menggunakan bahasa yang mudah } \\
\text { dipahami oleh siswa }\end{array}$ \\
\hline 6 & $\begin{array}{l}\text { LKS menggunakan sruktur kalimat yang } \\
\text { jelas }\end{array}$ \\
\hline 7 & $\begin{array}{l}\text { LKS menggunakan kalimat yang tidak } \\
\text { menimbulkan makna ganda }\end{array}$ \\
\hline 8 & $\begin{array}{l}\text { Petunjuk kegiatan-kegiatan dalam LKS } \\
\text { jelas sehingga mempermudah siswa mel- } \\
\text { akukan semua kegiatan yang ada dalam } \\
\text { LKS }\end{array}$ \\
\hline 9 & $\begin{array}{l}\text { Materi yang disajikan dalam LKS sesuai } \\
\text { dengan KI dan KD }\end{array}$ \\
\hline 10 & $\begin{array}{l}\text { Materi yang disajikan dalam LKS mem- } \\
\text { bantu siswa untuk mencapai tujuan pem- } \\
\text { belajaran yang telah diisyaratkan dalam } \\
\text { indikator pencapaian kompetensi dasar }\end{array}$ \\
\hline 11 & $\begin{array}{l}\text { Materi yang disajikan dalam LKS sesuai } \\
\text { dengan tingkat kemampuan siswa }\end{array}$ \\
\hline 12 & $\begin{array}{l}\text { LKS memfasilitasi siswa untuk memban- } \\
\text { gun pemahaman berdasarkan pengeta- } \\
\text { huan yang telah dimiliki sebelumnya }\end{array}$ \\
\hline 13 & $\begin{array}{l}\text { LKS memfasilitasi siswa untuk menggali } \\
\text { informasi yang dibutuhkan untuk menyel- } \\
\text { esaikan masalah }\end{array}$ \\
\hline
\end{tabular}




\begin{tabular}{ll}
\hline No & \multicolumn{1}{c}{ Pernyataan } \\
\hline 14 & $\begin{array}{l}\text { LKS mendorong siswa untuk berdiskusi } \\
\text { atau bekerja sama dengan orang lain da- } \\
\text { lam satu kelompok }\end{array}$ \\
15 & $\begin{array}{l}\text { Notasi, simbol, dan ikon dalam LKS disaji- } \\
\text { kan secara benar }\end{array}$ \\
16 & $\begin{array}{l}\text { LKS membantu siswa untuk menemukan } \\
\text { konsep materi transformasi geometri }\end{array}$ \\
17 & LKS mudah dipahami oleh siswa \\
18 & $\begin{array}{l}\text { LKS mudah diimplementasikan pada } \\
\text { pembelajaran }\end{array}$ \\
19 & $\begin{array}{l}\text { Masalah-masalah yang diberikan mudah } \\
\text { untuk dipahami }\end{array}$ \\
20 & $\begin{array}{l}\text { LKS berbasis budaya mampu meningkat- } \\
\text { kan rasa cinta akan budaya pada siswa }\end{array}$ \\
\hline
\end{tabular}

Tabel 7. Angket Respons Siswa

\begin{tabular}{ll}
\hline No & \multicolumn{1}{c}{ Pernyataan } \\
\hline 1 & $\begin{array}{l}\text { Lembar Kerja Siswa (LKS) menggunakan } \\
\text { bahasa yang mudah dipahami }\end{array}$ \\
2 & $\begin{array}{l}\text { LKS menggunakan kalimat yang tidak } \\
\text { menimbulkan makna ganda }\end{array}$ \\
3 & $\begin{array}{l}\text { Petunjuk kegiatan pada LKS jelas, seh- } \\
\text { ingga mempermudah dalam melakukan }\end{array}$ \\
& $\begin{array}{l}\text { kegiatan } \\
4\end{array}$ \\
& $\begin{array}{l}\text { Pemilihan jenis huruf, ukuran serta spasi } \\
\text { yang digunakan mempermudah dalam } \\
\text { membaca LKS }\end{array}$
\end{tabular}

5 Gaya penyajian LKS ini tidak membosankan

6 Variasi kegiatan, tugas, soal latihan, ilustrasi dan lain-lain membantu saya untuk mengembangkan kemampuan matematika Saya

7 Dari setiap kegiatan yang ada dalam LKS ini saya dapat menyimpulkan dan mengambil ide-ide penting mengenai materi tranformasi geometri

8 Saya dapat menghubungkan isi LKS ini dengan hal-hal yang telah saya lihat terutama pada rumah tembakau

9 Saya mampu membuat model matematika dari soal berbentuk uraian dan soal cerita

10 Saya memperoleh pengetahuan dengan mengikuti serangkaian kegiatan dalam lembar kerja siswa

11 Setelah mempelajari transformasi geometri menggunakan LKS ini saya percaya bahwa saya akan berhasil dalam tes

12 Isi LKS sangat bermanfat bagi saya

\begin{tabular}{ll}
\hline No & \multicolumn{1}{c}{ Pernyataan } \\
\hline 13 & $\begin{array}{l}\text { Saya senang mempelajari matematika } \\
\text { khususnya materi transformasi geometri } \\
\text { dengan menggunakan LKS ini }\end{array}$ \\
14 & $\begin{array}{l}\text { Saya lebih paham lagi tentang rumah tem- } \\
\text { bakau dengan adanya LKS ini }\end{array}$ \\
$15 \quad \begin{array}{l}\text { Dengan menggunakan LKS berbasis etno- } \\
\text { matematika pada rumah tembakau, saya } \\
\text { lebih cinta pada budaya }\end{array}$ \\
\hline
\end{tabular}

\section{Implementation (Implementasi)}

Tahap yang keempat yaitu implementation, setelah dinyatakan layak oleh validator ahli materi, ahli media, dan juga ahli pendidikan matematika serta merevisi LKS dan setelah itu LKS siap untuk diimplementasikan di sekolah. Sekolah yang dituju yaitu SMA Unggulan BPPT Darus Sholah. Tujuan dari implemntasi LKS yang telah dikembangkan yaitu untuk mengetahui kepraktisan dari LKS berbasis etnomatematika pada rumah tembakau materi transformasi geometri. Pada tahap ini dilakukan secara online yaitu dengan memberikan link google form bagi siswa dan guru dalam mengisi respon siswa dan guru terhadap LKS yang kembangkan.

Dalam pelaksanaan implementasi LKS, dilakukan terlebih dahulu pada skala kecil yang terdiri dari 6 responden atau siswa. Tujuan dari dilakukannya uji coba secara kecil yaitu untuk mengetahui sejauh mana produk yang dihasilkan sebelum produk tersebut diaplikasikan pada uji skala besar. Pada pelaksanaan uji skala besar diikuti oleh 30 siswa kelas XI.

Tabel 8. Hasil Validasi Ahli

\begin{tabular}{llrl}
\hline No & \multicolumn{1}{c}{ Validator } & Skor & Kriteria \\
\hline 1 & Masrurotullaily, & $82.5 \%$ & Sangat \\
& M.Sc. (Ahli Materi) & & Valid \\
2 & Dr. Umi Farihah, & $80 \%$ & Sangat \\
& $\begin{array}{l}\text { M.M, M.Pd. (Ahli } \\
\text { Desain) }\end{array}$ & & Valid \\
\hline
\end{tabular}


Indonesian Journal of Mathematics and Natural Science Education, 2 (2), 2021

Diana Rahayu, R. Ading Pramadi, Meti Maspupah, Tri Wabyuni Agustina

\begin{tabular}{llrl}
\hline No & \multicolumn{1}{c}{ Validator } & Skor & Kriteria \\
\hline 3 & Muh. Harawan & $94.3 \%$ & Sangat \\
& $\begin{array}{l}\text { Dimas J, M.Pd. (Ahli } \\
\text { Pendidikan Matem- } \\
\text { atika }\end{array}$ & & Valid \\
\hline Rata-rata Kevalidan & $85.6 \%$ & $\begin{array}{l}\text { Sangat } \\
\text { Valid }\end{array}$ \\
\hline
\end{tabular}

Berdasarkan hasil validasi yang dilakukan oleh validator materi, desain, dan pendidikan matematika, LKS memiliki kriteria kevalidan sangat valid, sehingga dapat digunakan uji coba kepada siswa namun setelah adanya revisi.

Tabel 9. Hasil Respon Guru dan Siswa

\begin{tabular}{|c|c|c|c|}
\hline No & Respon & Skor & Kriteria \\
\hline 1 & $\begin{array}{l}\text { Siswa Skala } \\
\text { Kecil }\end{array}$ & $81.1 \%$ & Sangat Praktis \\
\hline 2 & $\begin{array}{l}\text { Siswa Skala } \\
\text { Besar }\end{array}$ & $82.4 \%$ & Sangat Praktis \\
\hline 3 & Guru & $86 \%$ & Sangat Praktis \\
\hline & -rata Ke- & $83.2 \%$ & Sangat Praktis \\
\hline
\end{tabular}

Dari hasil di atas, diperoleh nilai kepraktisan LKS sebesar $83.2 \%$ dengan kriteria sangat praktis. Dengan demikian LKS berbasis etnomatematika materi transformasi geometri tidak peru direvisi.

\section{Evaluation (Evaluasi)}

Berdasarkan hasil analisis data di atas, dapat diperoleh bahwasannya produk LKS yang dikembangkan tidak perlu direvisi. Karena data hasil analisis kevalidan menunjukkan ratarata keseluruhan $85.6 \%$ dengan kriteria sangat valid. Sedangkan untuk hasil analisi kepraktisan menunjukkan ratarata keseluruhan $83.2 \%$ dengan kriteria sangat praktis. Dengan demikian produk LKS yang dikembangkan dapat dikatakan valid dan praktis.

\section{SIMPULAN}

Pada proses pengembangan LKS berbasis etnomatematika pada rumah tembakau materi transformasi geometri kelas XI mengacu pada model pengembangan ADDIE (Anlysis-Desain-Develop-ImplementEvaluate). Nilai kevalidan diperoleh dari pengisian lembar validasi oleh ketiga validator (ahli materi, desain, dan pendidikan matematika). Dari data hasil analisis kevalidan menunjukkan rata-rata keseluruhan 85.6\% dengan Kriteria sangat valid. Nilai kepraktisan diperoleh dari pengisian angket respon siswa dan guru yang dilakukan oleh siswa dan guru SMA Unggulan BPPT Darus Sholah Jember. Dari data hasil analisis keparktisan menunjukkan rata-rata keseluruhan 83.2\% dengan kriteria sangat praktis. Dengan demikian, produk LKS yang dikembangkan dapat dikatakan valid dan parktis

\section{DAFTAR PUSTAKA}

Annizar, Anas Ma'ruf. (2015). Analisis Kemampuan Pemecahan Masalah Soal PISA Menggunakan Model IDEAL pada Siswa Usia 15 Tahun di SMA Nuris Jember. Skripsi. Universitas Jember.

Ariaji, Risky, dan Abubakar. (2017). Pengembangan Lembar Kerja Siswa (LKS) Kimia di SMA/MA Kelas X Terinternalisasi Nilai-nilai Karakter Siswa. Jurnal Penelitian dan Pengembangan MIPA, 2(2).

Belawati. (2003). Pengembangan Bahan Ajar. Jakarta: Universitas Terbuka

Diki, Mateus, dkk. (2019). Pengembangan Bahan Ajar Transformsi Geometri Berorientasi pada Kemampuan Berpikir Kritis. Jurnal Matematika Kreatif-Inovatif, 10(1). 
Hanafi dan Sain. (2014). Konsep Belajar dan Pembelajaran. Jurnal Ilmu Tarbiyah, 17(1).

Novita, Eka dan Lestari, Anita. (2006). Efektifitas Metode Pembelajaran Gotong Royong (Cooperative Learning) untuk Menurunkan Kecemasan Siswa dalam Menghadapi Pembelajaran Matematika (Studi Ekspremental pada Siswa di SMP 26 Semarang). Jurnal Psikologi, 3(1).

Noviyanti, dan Gading Gamaputra. (2020). Model Pengembangan ADDIE dalam Penyusunan Buku Ajar Administrasi Keuangan Negara (Studi Kualitatif di Prodi D-III Administrasi Negara FISH Unesa). Jurnal Ilmiah Manajemen Publik dan Kebijakan Sosial. 4 (2).

Nur, Risa dan Wahyu. (2020). Metode Penelitian R\&D (research and Development). Malang: Literasi Nusantara

Prasetiyo, N. A dan Perwiraningtyas Pertiwi. (2017). Pengembangan Buku Ajar Berbasis Lingkungan Hidup Pada Matakuliah Biologi di Universitas Tribhuwana Tunggadewi. Jurnal Pendidikan Biologi Indonesia 3 (1).
Sitohang, Candra dan Sibuea, Abdul Muin. (2015). Pengembangan Buku Ajar Berbasis Kontekstual dengan Tema "Sehat Itu Penting". Jurnal Teknologi Informasi dan Komunikasi dalam Pendidikan. 2 (2).

Wahyuni, Tias, dan Sani. (2013). Peran Etnomatematika dalam Membangun Karakter Bangsa. Prosiding Jurusan Pendidikan Matematika FMIPA UNY, ISBN: 978-979-16353-9-4.

\section{PROFIL SINGKAT}

Yusril Achmad Fatoni lahir di Jember, 04 Juni 1998. Menempuh pendidikan di SD N Gebang 01 Jember, SMP N 2 Jember, SMA N 1 Jember, dan masuk ke perguruan tinggi UIN KHAS Jember pada tahun 2017-2021, saat ini menempuh Magister Pendidikan Matematika di Univeritas Jember. 